\title{
CONCEPT OF DESIGN, REQUIREMENTS AND GENERALIZED ARCHITECTURES OF COMPONENTS OF THE INTEGRATED ONTO- ORIENTED INFORMATION ENVIRONMENT OF SIMULATION AND PROCESSING OF CYCLIC SIGNALS
}

\author{
Serhii Lupenko $^{1}$; Iaroslav Lytvynenko ${ }^{1}$; Volodymyr Hotovych ${ }^{1}$; \\ Andrii Zozulia $^{2}$; Nnamene Chizoba ${ }^{1}$; Oleksandr Volyanyk ${ }^{2}$ \\ ${ }^{1}$ Ternopil Ivan Pului National Technical Univesity, Ternopil, Ukraine \\ ${ }^{2}$ Institute of Telecommunications and Global Information Space of \\ National Academy of Sciences of Ukraine, Kyiv, Ukraine
}

\begin{abstract}
Summary. The article gives the reasoning to the relevance of developing a generalized architecture of integrated onto-oriented information environment for simulation and processing of cyclic signals based on the theory of cyclic functional relations, as well as formulates the general requirements to it and its developingt. The research deals with statement of and creating the generalized architectures of the components of the integrated onto-oriented information environment for simulation and processing of cyclic signals, namely, for informationoriented reference system in the field of simulation and processing of cyclic signals; knowledge base of the integrated information environment, the core of which is the corresponding ontology; onto-oriented expert decision support system in the field of simulation and processing of cyclic signals; information system with ontooriented architecture for simulation and processing of cyclic signals.
\end{abstract}

Key words: ontology, integrated onto-oriented information environment, simulation, processing methods, cyclic signals.

https://doi.org/10.33108/visnyk_tntu2021.02.147

Received 11.03.2021

Introduction. Many scientific works are devoted to the development of mathematical models, methods of computer simulation and processing of signals of cyclic structure, as well as the creation of appropriate information systems for their analysis, prediction, classification, clustering, regression, prediction, simulation (generation) of cyclic signals [124]. There are many mathematical models of cyclic signals known which are developed within the framework of both deterministic and stochastic approaches to their description. Among deterministic models, the best known are harmonic and quasiharmonic functions, periodic and almost periodic polyharmonic functions that describe the temporal structure of cyclic signals, and models in the form of a series of linear and nonlinear differential (or difference) equations that describe the mechanisms of formation (generation) of such signals. Among stochastic mathematical models of cyclic signals, periodically correlated and periodically distributed random processes, periodic white noises (processes with independent periodic values), linear periodic random processes and fields, Markov periodic random processes, almost periodic, in particular, polyperiodic random processes have become classics.

Theory of simulation and processing of cyclic signals has received considerable development and systematization through the framework of the mathematical theory of cyclic functional relations (CFR), which significantly generalized the known mathematical models of signals and processes of cyclic structure [25-30]. CFR theory contains all the necessary prerequisites for creating a unified scientific methodology for developing new models, 
substantiation, structural and parametric identification of mathematical and computer models, methods of transformation, analysis and prediction of cyclic signals in modern intellectualized information systems using deterministic, stochastic, indistinct and interval approaches. Within the framework of this approach, new mathematical models, processing methods (statistical evaluation, spectral analysis, sampling) and computer simulation methods of cyclic signals of biological, economic and technical origin have been developed. In particular, the stochastic method actively uses and develops mathematical models in the form of cyclic random processes and vectors, as well as conditional cyclic random processes that generalize periodic (periodically correlated and periodically distributed) random processes and vectors, and have formal means of taking into account rhythm variability of the cyclic signals to be investigated. Based on these mathematical models and methods of cyclic signal processing, a number of software systems for analysis and prediction of cyclic signals (processes) in the field of medical cardiodiagnostics, econometrics and non-destructive diagnostics of materials have been developed [25-30].

Relevance of developing the integrated onto-oriented information environment for simulation and processing of cyclic signals (IOIS_SPCS) based on CFR theory. Such a wide variety of mathematical models, methods of processing and computer simulation of cyclic signals, as well as software that automates these methods, on the one hand, provides significant opportunities for developing effective information systems for diagnosing, predicting and assessing the state of cyclic signals. which are generated by them, and on the other - significantly complicates the developer of such systems the choice of mathematical software (models, methods and algorithms) and software that underlie the functioning of this class of information systems. This situation is further complicated by the fact that often collective developers do not have a direct specialist in the field of mathematical simulation and processing of cyclic signals, as well as the fact that software development often needs to be done 'from scratch'.

Given the above, it is important to develop an intellectualized (in particular, onto-oriented) information environment of deductive-inductive simulation (mathematical and computer) and processing (analysis, prediction, recognition, diagnosis, authentication) of cyclic signals (phenomena, processes) in the interval, stochastic and indistinct indeterminacies with guaranteed accuracy and reliability, minimal complexity (structural and computational complexity) and interpretability. This integrated information environment should have a user-friendly interface and a hierarchically organized system of software modules for computational experiments using the tools of CFR theory. In addition, this information environment should be equipped with an expert decision support system in the field of simulation and processing of cyclic signals, which will significantly simplify, intensify (automate) and increase the adequacy of the procedure for developing mathematical and software intelligent systems in medicine, technology and economics. After all, it is more appropriate to reasonably choose and adapt (according to the structure of the studied signals and research objectives) the mathematical model and methods from the existing, pre-formed and structured set, which will significantly increase efficiency (significantly simplify and accelerate) and development of mathematical software, in particular, by involving corresponding automation means which have already been developed.

Requirements and generalized IOIS_SPCS architecture. We formulate general requirements for IOIS_SPCS.

The proposed (IOIS_SPCS) as its components should include the following systems: information-oriented reference system in the field of simulation and processing of cyclic signals (IORS_SPCS); knowledge base of the integrated information environment (KB_IOIE), the core of which is the ontology of the subject area 'Simulation and processing 
of cyclic signals within the theory of cyclic functional relations' (OSA_SPCS); expert ontooriented decision support system in the field of simulation and processing of cyclic signals (EOS_SPCS), information system with onto-oriented architecture for simulation and processing of cyclic signals (ISOA_SPCS) (Fig. 1).

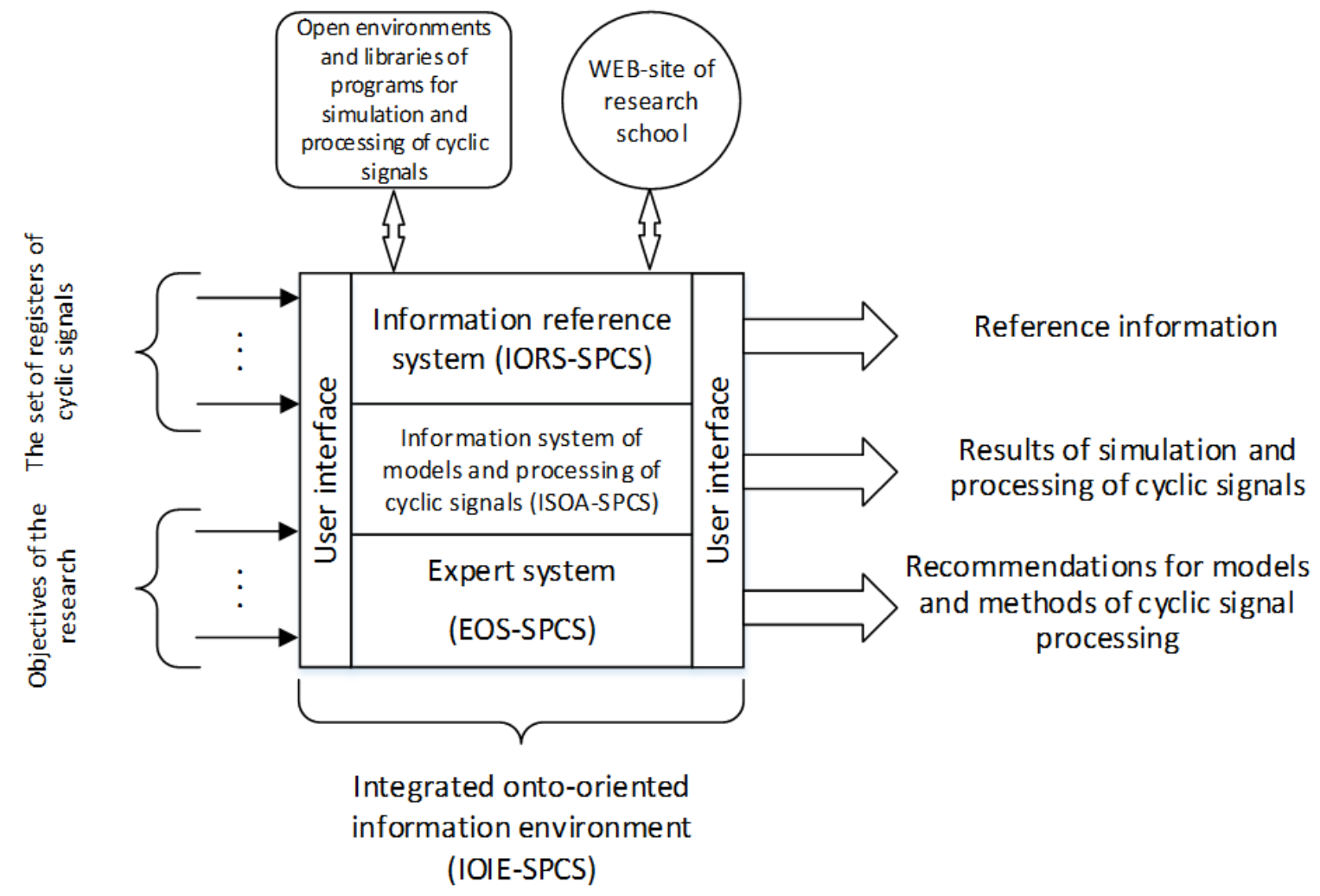

Figure 1. Generalized scheme of interaction of the integrated onto-oriented information environment of simulation and processing of cyclic signals with existing programs libraries, systems and resources in the field of simulation and processing of signals and images

IOIS_SPCS has to be based on an ontological approach to simulation and specification of knowledge in the subject area 'Simulation and processing of cyclic signals in the theory of cyclic functional relations'.

IOIS_SPCS has to be consistent (compatible) with existing libraries of programs, systems and resources in the field of simulation and processing of signals and images, in particular, signals and images with cyclic spatio-temporal structures.

IOIS_SPCS has to be developed using modern management technologies and quality assurance of software systems based on international standards.

IOIS_SPCS has to be web-based and can be implemented on a computing cluster as a virtual remote engineering lab.

IOIS_SPCS must have a modular structure with capability to increase functionality.

IOIS_SPCS has to be available (simple and inexpensive), and for this reason should it modeveloped using free open source software (including in the Python programming language).

The generalized IOIS_SPCS architecture is presented in Fig. 2. 


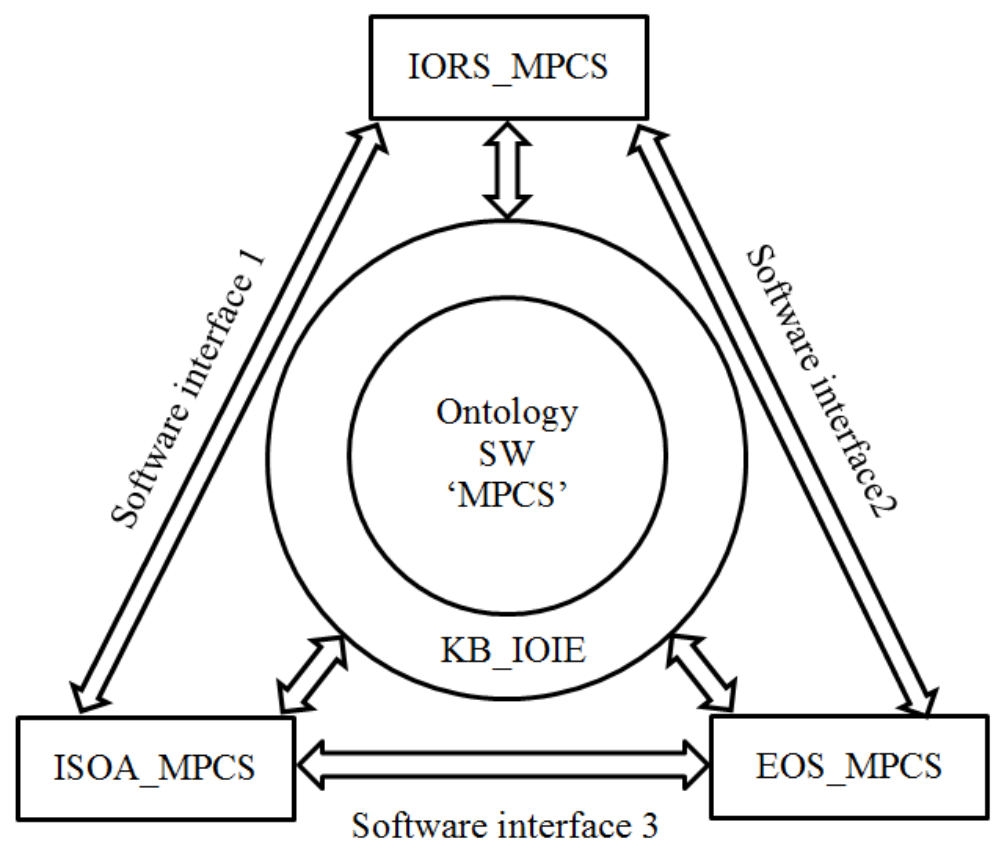

Figure 2. Generalized architecture of the integrated onto-oriented information environment of simulation and processing of cyclic signals

Requirements and generalized architectures of IOIS_SPCS components. Consider in more detail the components of the proposed IOIS_SPCS, as well as their generalized architectures.

Onto-oriented knowledge base and ontology of the subject area «Simulation and processing of cyclic signals». An important fundamental component of the integrated ontooriented information environment for simulation and processing of cyclic signals is its knowledge base KB_SPCS, because the logic of all components of the integrated environment is based on a previously developed knowledge base. The OSA_SPCS ontology provides knowledge about models and methods of cyclic signal processing in machine-interpreted form, namely, it allows to specify knowledge about the system of models, methods and software for cyclic signal processing.

The main requirements for KB_SPCS are the following.

1. Knowledge base of KB_SPCS has to contain its five main components: 1) knowledge base of mathematical models of cyclic signals; 2) knowledge base of typical tasks of processing and computer simulation of cyclic signals; 3 ) knowledge base of methods of processing and computer simulation of cyclic signals; 4) knowledge base of means (software, firmware, hardware) of processing and computer simulation of cyclic signals; 5) knowledge base of the results of application of models, methods and means of processing and computer simulation of cyclic signals in the relevant fields of medicine, engineering and economics (Fig. 3).

2. Knowledge base of mathematical models of cyclic signals should have the highest priority (priority 1); the knowledge base of typical tasks of processing and computer simulation of cyclic signals should have the second most important priority (priority 2); the knowledge base of methods of processing and computer simulation of cyclic signals should have the third most important priority (priority 3); the knowledge base of the means (software, firmware, hardware) of processing and computer simulation of cyclic signals should have the fourth most important priority (priority 4); the knowledge base of the results of application of models, 
methods and means of processing and computer simulation of cyclic signals should have the fifth most important priority (priority 5). Taking into account the priority of KB_SPCS components makes it possible to structure models, typical tasks, methods and tools, as well as the results of their practical application.

3. The structure of KB_SPCS should be consistent with the axiomatic-deductive strategy of CFR theory as a theory of cyclic signal models.

4. The knowledge base KB_SPCS should have an ontology of the subject area «Modeling and processing of cyclic signals based on the theory of cyclic functional relations» (OSA_SPCS) as its core.

5. The OSA_SPCS ontology has similar structural components as the KB_SPCS knowledge base (see Figure 3).

6. The OSA_SPCS ontology has to contain the following four objects: 1) glossary (models, methods, algorithms, programs - the formal generating grammar of CFR class names and names of corresponding methods (algorithms, programs), as well as their corresponding definitions should work here); 2) system of four taxonomies (taxonomies of mathematical models, taxonomy of methods (taxonomy of methods of computer simulation of cyclic signals, taxonomy of methods of cyclic signals processing (analysis, prediction, transformation, classification, clustering, regression, sampling, etc.)), software taxonomy and taxonomy of application results); 3) taxonomy of slots that contain attribute vectors for each CFR class (these attributes characterize the corresponding CFR class in terms of features and capabilities of its use as a model of cyclic signals, taking into account the capabilities of appropriate methods); 4) a set of expert descriptions of each CFR class in terms of the characteristic conditions of applicability of this class as a model of cyclic signals.

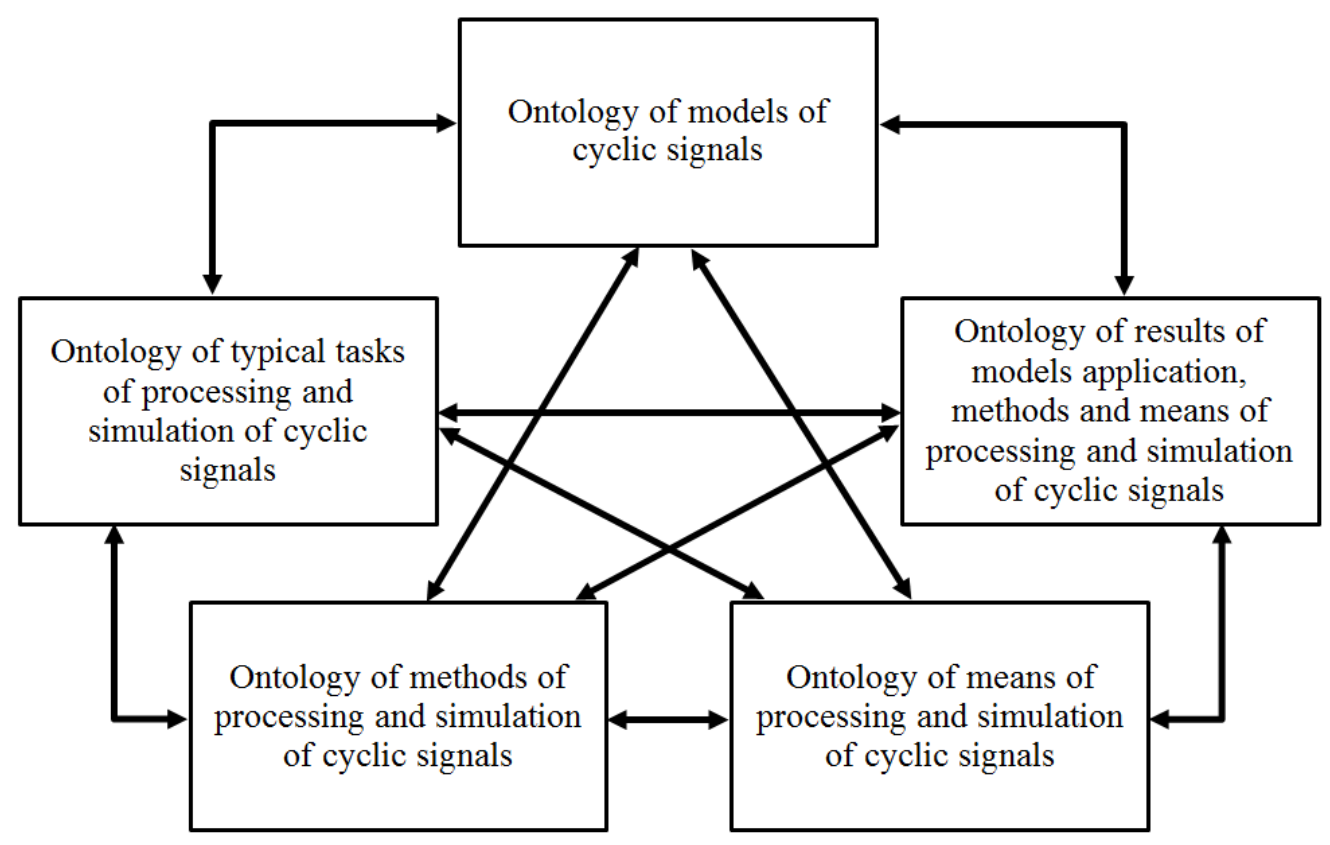

Figure 3. Symbolic image of the structural components of OSA_SPCS ontology

Ontology makes it possible to present CFR theory in a machine-interpreted form and to be the basis for the development of onto-oriented information systems for simulation, generating, processing (analysis, forecasting, decision-making) of cyclic signals. In addition, the ontological approach is well consistent with the axiomatic-deductive strategy of the theory of simulation and processing of cyclic signals. Axiomatic-deductive strategy of the theory of 
Concept of design, requirements and generalized architectures of components of the integrated onto-oriented information environment of simulation and processing of cyclic signals

simulation and processing cyclic signals significantly increases the level of its structure, rigor and formalization, facilitates the identification of new directions and regions of development of CFR theory.

The presence in the ontology of many expert descriptions of each CFR class in terms of the characteristic conditions of this class applicability as a model of cyclic signals will allow the expert decision support system in addition to recommendations of a particular class of CFR as a model of studied signals. Such descriptions are formed on the basis of a survey carried out by several experts of the highest qualification in the field of mathematical simulation and methods of processing cyclic signals.

Information-oriented reference system in the field of simulation and processing of cyclic signals. The information-oriented reference system in the field of simulation and processing of cyclic signals (IORS_SPCS) is designed to provide access to information about existing mathematical models, methods and software for processing and computer simulation of cyclic signals within the CFR theory.

We formulate the basic requirements for IORS_SPCS.

1. IORS_SPCS should include: 1) graphical user interface; 2) software interfaces for EOS_SPCS and ISOA_SPCS information systems access to IORS_SPCS content; 3) a database containing the content of the theory of simulation and processing cyclic signals; 4) module for editing and replenishing content (see Fig. 3).

2. IORS_SPCS has to be a stand-alone reference system with access to its resources of other components of the IOIS_SPCS integrated environment, namely: in the process of interaction with the expert system EOS_SPCS at intermediate stages and at the final stage of recommending the optimal class of mathematical models, methods and tools computer simulation of cyclic signals, providing information from the directory relevant to the stage of user interaction with EOS_SPCS; in the process of user interaction with ISOA_SPCS, providing access to content at different stages of processing and computer simulation of cyclic signals; in the process of user interaction with the knowledge base KB_IOIE and the OSA_SPCS ontology of the integrated information environment. That is, access to IORS_SPCS has to be in two modes: 1) in the full-fledged work mode with the reference system; 2) in the mode of partial access to the reference material from the dialog boxes of other information systems of the integrated environment.

3. IORS_SPCS content has to be structured according to the axiomatic-deductive strategy of content organization and based on the previously developed OSA_SPCS ontology. In particular, the structural organization of IORS_SPCS is determined by taxonomies of models, methods and tools of processing and computer simulation, which are part of the previously developed ontology of OSA_SPCS. That is, the IORS_SPCS sections have the names of the CFR classes and the corresponding methods and means of their simulation and processing.

4. IORS_SPCS has to be equipped with means of automatic content generation using the technology of text dynamic templates in accordance with the sub-strategy of taxonomic distribution of content from the abstract logical-semantic core of simulation theory and processing of cyclic signals into a set of its partial logical-semantic regions. More precisely, the first (abstract) part of the electronic directory should be generated automatically, and the second (specifically-partial) should be formed in the 'manual' mode. Thus, each class of mathematical models corresponds to its own help text, the first part of which is generated automatically, and the second in the usual 'manual' mode.

5. The IORS_SPCS reference system must be multilingual with the ability to imply other languages. 
6. The IORS_SPCS reference system must be equipped with a hyperlink mechanism for transitions between basic content concepts.

The generalized IORS_SPCS architecture is presented in Fig. 4.

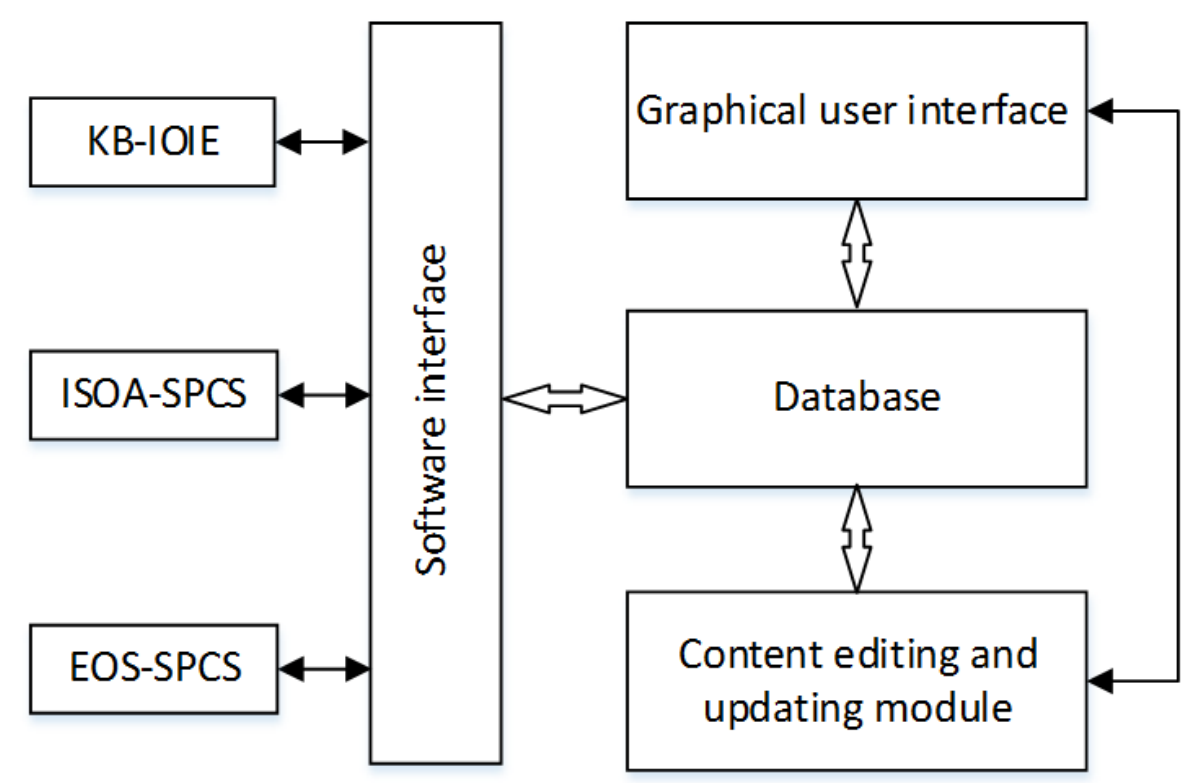

Figure 4. Generalized architecture of information-oriented reference system in the field of simulation and processing of cyclic signals

Onto-oriented expert decision support system in the field of simulation and processing of cyclic signals. An important component of the developed integrated information environment is an expert decision support system in the field of simulation and processing of cyclic signals (EOS_SPCS). The main purpose of the expert system is to form substantiated recommendations, optimal in a sense (according to a certain criterion of optimality) such objects: 1) CFR class, within which there is a corresponding cyclic functional relationship that can be used as an adequate mathematical model of the studied cyclic signals; 2) a specific mathematical model of cyclic signals from this CFR class; 3) methods of processing and/or methods of computer simulation of cyclic signals, which are based on the recommended mathematical model; 4) tools (software, firmware, hardware) that automate (implement) the appropriate methods of processing and/or methods of computer simulation of cyclic signals.

EOS_SPCS users can be researchers, engineers who are not highly qualified direct specialists in the field of simulation and processing of cyclic signals, but who need to solve problems in this field, in particular, using an information system with onto-oriented architecture for simulation and processing of cyclic signals.

The main requirements for the designed expert system include the following.

1. The expert system EOS_SPCS should include: 1) graphical user interface and administrator (knowledge engineer); 2) software interfaces for access to information systems IORS_SPCS, ISOA_SPCS and KB_SPCS; 3) module to form recommended solutions; 4) module of explanations and justifications. 
Concept of design, requirements and generalized architectures of components of the integrated onto-oriented information environment of simulation and processing of cyclic signals

2. The expert system has to be an independent information system with the possibility of access to other components of the integrated environment IOIS_ MOCS: IORS_SPCS, ISOA_SPCS and KB_SPCS.

3. The expert system has to be able to justify its decision, explain it in the form of a logical conclusion from the request (needs) of the user.

4. The knowledge base of the expert system has to be based on a pre-developed ontology of simulation and processing of cyclic signals on CFR theory background.

5. The procedure for selecting the optimal class of mathematical models of the expert system should be carried out both on the basis of a specific user survey (a priori information) and with the simultaneous involvement of software to test statistical hypotheses regarding certain properties of the studied cyclic signals (a posteriori information).

6. The optimal choice of a specific model from the appropriate class and methods of processing should be based on the procedure of its structural or structural-parametric identification by machine learning methods based on real data - the implementation of the studied cyclic signals.

Generalized architecture of the expert decision support system in the field of simulation and processing of cyclic signals is presented in Fig. 5.

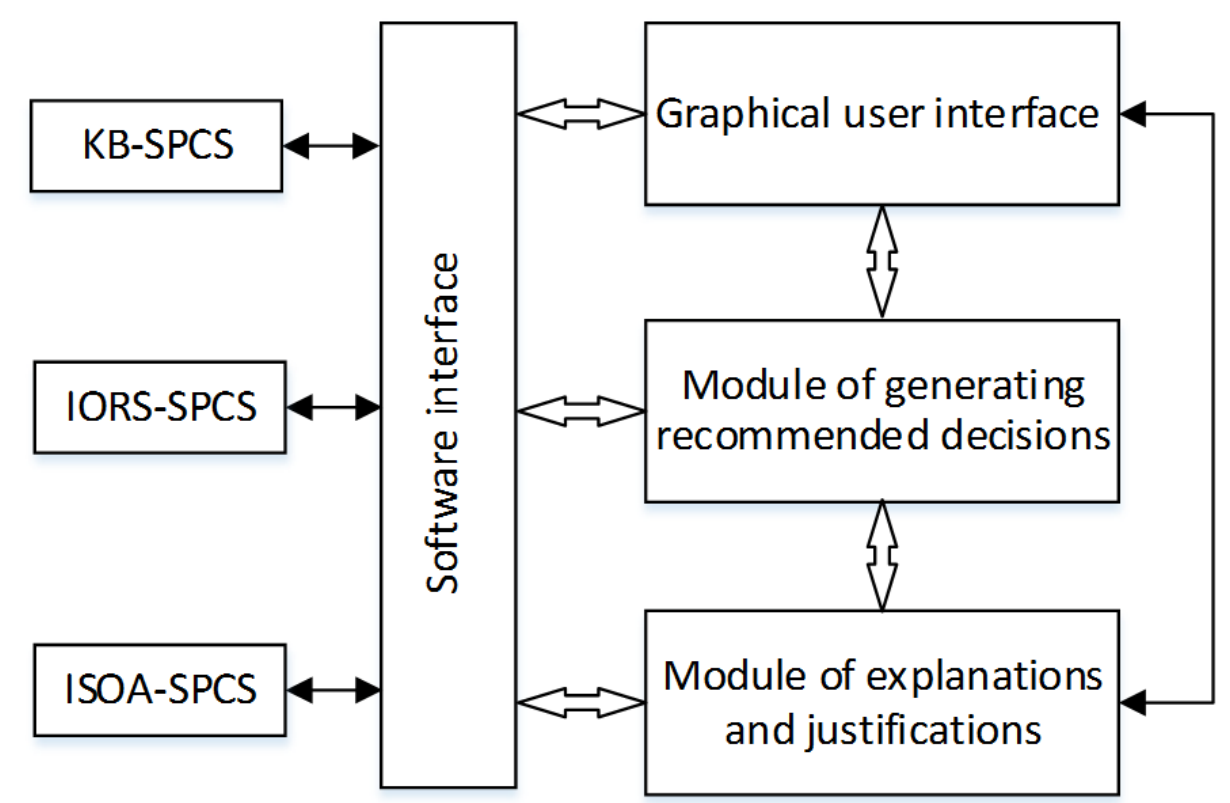

Figure 5. Generalized architecture of the expert decision support system in the field of simulation and processing of cyclic signals (EOS_SPCS)

Based on the above, four basic stages of EOS_SPCS operation can be distinguished, namely: 1) stage of selection (recommendation) of the relevant user request (such as task processing or simulation of cyclic signal) and adequate spatio-temporal structure of cyclic signals class mathematical models as CFR class; 2) the stage of selection (structuralparametric identification) of a specific mathematical model from this class using machine learning technologies; 3) the stage of selection of means that automate (implement) the corresponding methods of processing and/or methods of computer simulation of cyclic signals and 4) the stage of selection of methods for solving problems of processing and simulation of cyclic signals (Fig. 6). 


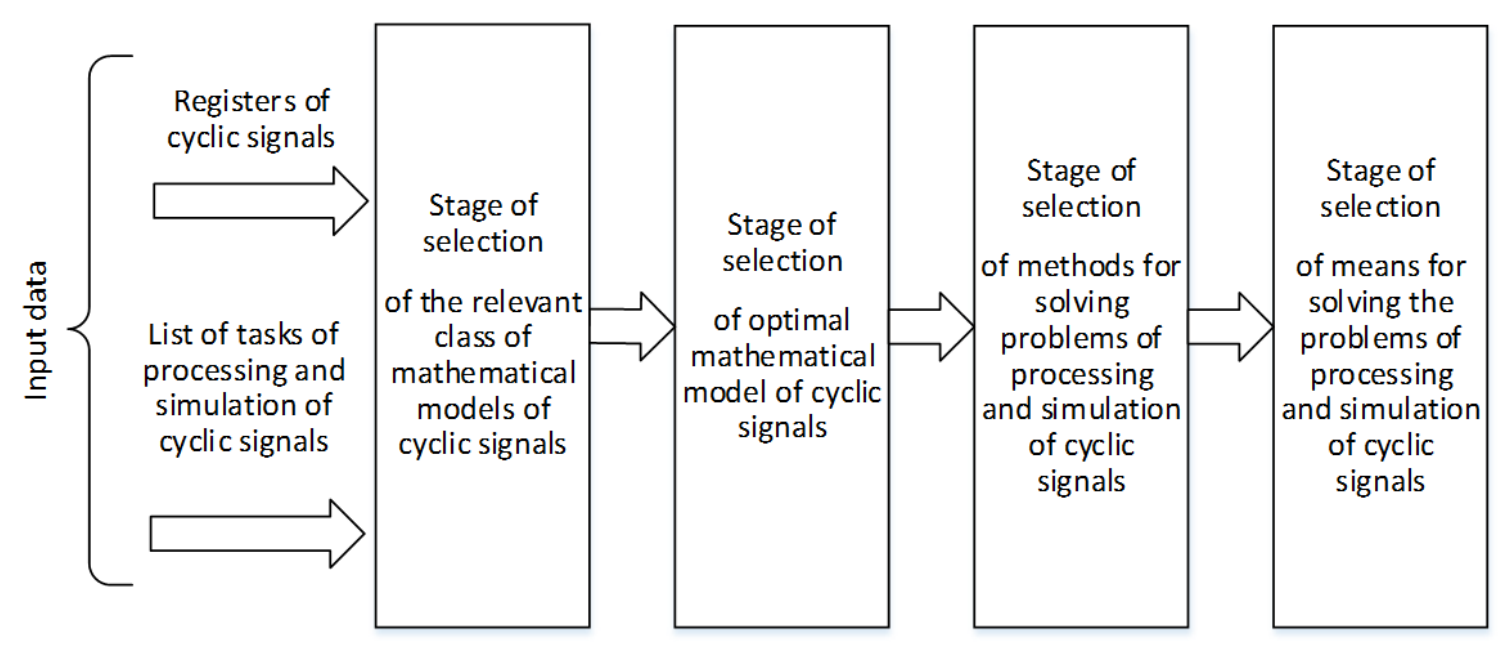

Figure 6. Basic stages of EOS_SPCS operation support of decision support in the field of simulation, processing and computer simulation of cyclic signals

Information system with onto-oriented architecture for simulation and processing of cyclic signals. The most complex and largest subsystem that is part of the integrated information environment is an information system with an onto-oriented architecture for simulation and processing of cyclic signals (ISOA_SPCS).

The generalized ISOA_SPCS architecture is presented in Fig. 7.

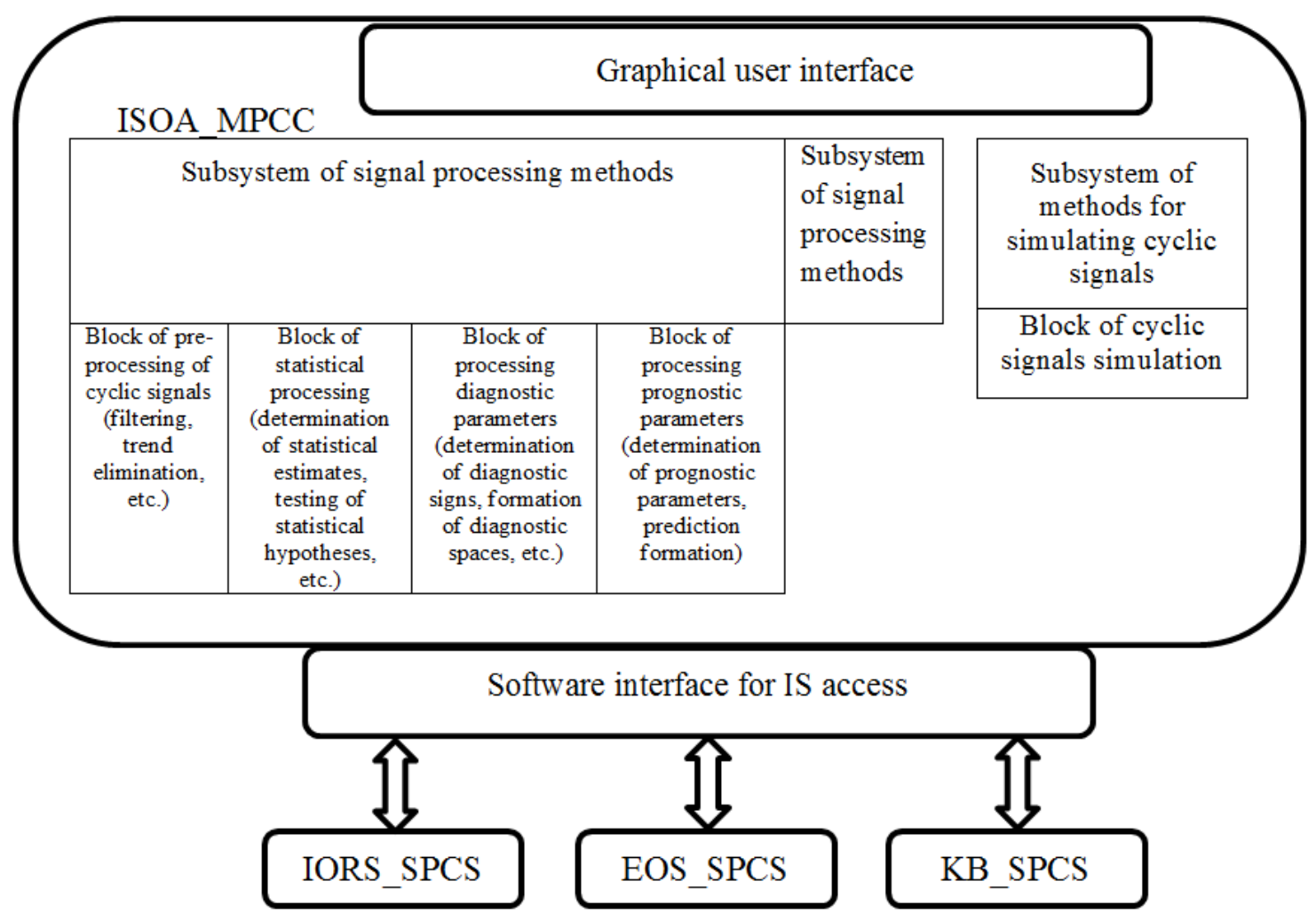

Figure 7. Generalized architecture of the information system with onto-oriented ISOA_SPCS architecture 
The main purpose of ISOA_SPCS is to automate all known methods of processing and computer simulation of cyclic signals in the framework of CFR theory, which will allow the researcher of cyclic signals (processes, phenomena) and the developer of appropriate information systems for their analysis and prediction to effectively process and digitally simulate signals, as well as to create the necessary information systems for diagnosis and prediction of these signals.

The main requirements for an information system with an onto-oriented architecture include the following.

1. ISOA_SPCS has to include: 1) graphical user interface; 2) software interfaces for access to information systems IORS_SPCS, EOS_SPCS and KB_SPCS; 3) information subsystem of cyclic signal processing methods; 4) information subsystem of methods for computer simulation of cyclic signals.

2. Information system with onto-oriented architecture ISOA_SPCS has to be a standalone information system with access to other components of the integrated environment IOIS_SPCS: IORS_SPCS, EOS_SPCS and KB_SPCS.

The architectures of information subsystems of processing methods and methods of computer simulation of cyclic signals must be onto-oriented, i.e., the set of modules of these subsystems and their mutual subordination is completely determined by OSA_SPCS ontology.

\section{Conclusions and prospects for further research.}

1. The relevance of IOIS_SPCS development is substantiated, which enables effective system solution of a whole range of important methodological, methodical and technological tasks in the field of simulation and processing of cyclic signals, in particular, significantly simplifies, intensifies (automates) and increases the reliability of mathematical and software systems for the needs of medicine, technology and economics.

2. The main tasks of development are formulated and the generalized IOIS_SPCS architecture is developed.

3. The requirements are formulated and generalized architectures of the following components of IOIS_SPCS are developed: information onto-oriented reference system in the field of simulation and processing of cyclic signals; knowledge base of the integrated information environment, the core of which is the ontology of the subject area «Simulation and processing of cyclic signals in the theory of cyclic functional relations»; expert onto-oriented decision support system in the field of simulation and processing of cyclic signals, information system with onto-oriented architecture for simulation and processing of cyclic signals.

The main problems that need further solution are the following.

1. Create mathematical software for the developed integrated information environment, namely, the necessary models (analytical, simulation), methods and algorithms for functioning of this integrated environment and its components of information systems.

2. Taking into account the specifics of mathematical support, to model, analyse and optimize the structural (architectural) and functional properties of the developed integrated onto-oriented information environment, and create a detailed (refined) project of integrated onto-oriented information environment and its components.

3. To substantiate the choice of information technologies and software environments for realization (coding, programming) of the project of the integrated onto-oriented information environment of simulation and processing of cyclic signals.

\section{References}

1. Gardner W., Napolitano A., L. Paura Cyclostationarity: Half a century of research. Signal Processing. 2005. Vol. 86. P. 639-697. DOI: https://doi.org/10.1016/j.sigpro.2005.06.016 
2. Gardner W., Archer T. Exploitation of cyclostationarity for identifying the Volterra kernels of non-linear systems. IEEE Transactions on Information Theory. 1993. No. 39 (2). P. 535-542. DOI: https://doi.org/10.1109/18.212283

3. Gardner W., Brown W. Fraction of time probability for time-series that exhibit cyclostationarity. Signal Processing. 1991. Vol. 23. P. 273-292. DOI: https://doi.org/10.1016/0165-1684(91)90005-4

4. Israa Shaker Tawfic, Sema Koc Kayhan. (2017) Improving recovery of ECG signal with deterministic guarantees using split signal for multiple supports of matching pursuit (SSMSMP) algorithm, Computer Methods and Programs in Biomedicine. Vol. 139. 2017. P. 39-50. DOI: https://doi.org/10.1016/j.cmpb.2016.10.014

5. Fumagalli F., Silver A. E., Tan Q., Zaidi N., Ristagno G. (2018), Cardiac rhythm analysis during ongoing cardiopulmonary resuscitation using the Analysis During Compressions with Fast Reconfirmation technology, Heart Rhythm, 15 (2). P. 248-255. DOI: https://doi.org/10.1016/j.hrthm.2017.09.003

6. Napoli N. J., Demas M. W., Mendu S., Stephens C. L., Kennedy K. D, Harrivel A. R, Bailey R. E., Barnes L.E. (2018), Uncertainty in heart rate complexity metrics caused by R-peak perturbations, Computers in Biology and Medicine. 103. P. 198-207. DOI: https://doi.org/10.1016/j.compbiomed.2018.10.009

7. Napolitano A. (2016) Cyclostationarity: Limits and generalizations. Signal Processing. Vol. 120. March 2016. P. 323-347. DOI: https://doi.org/10.1016/j.sigpro.2015.09.013

8. Lepage R., Boucher J., Blan J. and Cornilly J., "ECG segmentation and p-wave feature extraction: application to patients prone to atrial fibrillation", IEEE EMBS 2001; 1:298-301.

9. Moody B. G. and Mark R. G., "A new method for detecting atrial fibrillation using R-R intervals", IEEE Computers in Cardiology 1983; 10:227-230.

10. Cerutti S., Mainardi L. T., Porta A. and Bianchi A. M., “Analysis of the Dynamics of RR Interval Series for the Detection of Atrial Fibrillation Episodes", IEEE Computers in Cardiology 1997; 24:77-80.

11. Tateno K. and Glass L., "A Method for Detection of Atrial Fibrillation Using RR intervals", IEEE Computers in Cardiology 2000; 27:391-394.

12. Karyotis V., Khouzani M. H. R. (2016) Malware Diffusion Models for Modern Complex Networks. Theory and Applications. USA. 2016. P. 324. ISBN 978-0-12-802714-1.

13. Sericola B. (2013) Markov Chains: Theory and Applications. London, July 2013. P. 416. ISBN: 978-1848-21493-4. DOI: https://doi.org/10.1002/9781118731543.ch1

14. Shaffer F., Ginsberg J. P. (2017), An Overview of Heart Rate Variability Metrics and Norms, Frontiers in Public Health. Volume 5. Article 258. September 2017. P. 1-17. DOI: https://doi.org/10.3389/fpubh.2017.00258

15. Berkaya S. K., Uysal A. K., Gunal E. S, Ergin S., Gunal S., Gulmezoglu M. B. (2018), A survey on ECG analysis. Biomedical Signal Processing and Control, 43, $216-235$. DOI: https://doi.org/10.1016/j.bspc.2018.03.003

16. Shen C., Yu Z., Liu Z. (2015), The use of statistics in heart rhythm research: a review, Heart Rhythm, 12 (6), 1376-1386. DOI: https://doi.org/10.1016/j.hrthm.2015.03.016

17. Peter Olofsson, Mikael Andersson. Probability, Statistics, and Stochastic Processes. John Wiley \& Sons, INC, 2012. USA. P. 553. DOI: https://doi.org/10.1002/9781118231296

18. Athanasios Christou Micheas. Theory of Stochastic Objects Probability, Stochastic Processes and Inference. Chapman and Hall/CRC. January 24. 2018. P. 408. ISBN: 9781466515215.

19. Hisashi Kobayashi, Brian L. Mark, William Turin. Probability, Random Processes, and Statistical Analysis. USA by Cambridge University Press, New York 2012. -p.812. Hardback 978-0-521-89544-6.

20. Oliver C. Ibe. Fundamentals of Applied Probability and Random Processes. 2nd Edition. Academic Press is an imprint of Elsevier. USA 2014. P. 431.

21. Scott Miller, Donald Childers Probability and Random Processes: With Applications to Signal Processing and Communications. 2nd Edition. Academic Press is an imprint of Elsevier. USA 2012. P. 593. DOI: https://doi.org/10.1016/B978-0-12-386981-4.50011-4

22. Ben Salah R., Hadidi T. and Chabchoub S., "Intelligent diagnosis method of cardiovascular anomalies using medical signal processing," 2015 World Congress on Information Technology and Computer Applications (WCITCA), Hammamet, 2015, P. 1-5. DOI: https://doi.org/10.1109/WCITCA.2015.7367032

23. Rahimpour M., Asl M. E. and Merati M. R., "ECG fiducial points extraction using QRS morphology and adaptive windowing for real-time ECG signal analysis," 2016 24th Iranian Conference on Electrical Engineering (ICEE). Shiraz. 2016. P. 1925-1930. DOI: https://doi.org/10.1109/IranianCEE.2016.7585836

24. Ciucurel C., Georgescu L., Iconaru E. I. (2018), ECG response to submaximal exercise from the perspective of Golden Ratio harmonic rhythm, Biomedical Signal Processing and Control, 40, 156-162. DOI: https://doi.org/10.1016/j.bspc.2017.09.018 
Concept of design, requirements and generalized architectures of components of the integrated onto-oriented information environment of simulation and processing of cyclic signals

25. Onyskiv P., Lupenko S., Lytvynenko I., Zozulia A. Mathematical modeling and processing of high resolution rhythmocardio signal based on a vector of stationary and stationary related random sequences. IDDM'2020: 3rd International Conference on Informatics \& Data-Driven Medicine, November 19-21, 2020, Växjö, Sweden. CEUR Workshop Proceedings, 2020, 2753, pp. 149-155. URL: http://ceurws.org/Vol-2753/short8.pdf.

26. Gorkunenko A. B., Lupenko S. A. Obg'runtuvannja diagnostychnyh i prognostychnyh oznak v informacijnyh systemah analizu ta prognozuvannja cyklichnyh ekonomichnyh procesiv. Naukovyj visnyk NLTU Ukrainy: zbirnyk naukovo-tehnichnyh prac. L'viv. 2012. No. 22.9. P. 347-352. [In Ukrainian].

27. Lupenko S., Lytvynenko I., Stadnyk N. Method for reducing the computational complexity of processing discrete cyclic random processes in digital data analysis systems Scientific Journal of the Ternopil national technical university. 2020. Vol. 97. No. 1. P. 110-121. URL: https://doi.org/10.33108/visnyk_tntu. DOI: https://doi.org/10.33108/visnyk_tntu2020.01.110

28. Lupenko S., Lytvynenko I., Stadnyk N., Zozulia A. та інші Mathematical model of rhythmocardiosignal in vector view of stationary and stationary-related case sequences. Advanced Information Systems. National Technical University "Kharkiv Polytechnic Institute". 2020. Vol. 4. No. 2. P. 42-46. DOI: https://doi.org/10.20998/2522-9052.2020.2.08

29. Hutsaylyuk V., Lytvynenko I., Maruschak P., Schnell, G. та iншi.A new method for modeling the cyclic structure of the surface microrelief of titanium alloy ti6al4v after processing with femtosecond pulses. Materials, 2020, 13(21), pp. 1-8, 4983. DOI: https://doi.org/10.3390/ma13214983

30. Marushak P. O., Lytvynenko I. O., Lupenko S. A., Popovych P. V. Modeling of the Ordered Surface Topography of Statically Deformed Aluminum Alloy. Materials Science. 2016. Vol. 52. No. 1. P. 113-122. DOI: https://doi.org/10.1007/s11003-016-9933-1

\section{Список використаної літератури}

1. Gardner W., Napolitano A., L. Paura Cyclostationarity: Half a century of research. Signal Processing. 2005. Vol. 86. P. 639-697. DOI: https://doi.org/10.1016/j.sigpro.2005.06.016

2. Gardner W., Archer T. Exploitation of cyclostationarity for identifying the Volterra kernels of non-linear systems. IEEE Transactions on Information Theory. 1993. No. 39 (2). P. 535-542. DOI: https://doi.org/10.1109/18.212283

3. Gardner W., Brown W. Fraction of time probability for time-series that exhibit cyclostationarity. Signal Processing. 1991. Vol. 23. P. 273-292. DOI: https://doi.org/10.1016/0165-1684(91)90005-4

4. Israa Shaker Tawfic, Sema Koc Kayhan. (2017) Improving recovery of ECG signal with deterministic guarantees using split signal for multiple supports of matching pursuit (SSMSMP) algorithm, Computer Methods and Programs in Biomedicine. Vol.139. 2017. P. 39-50. DOI: https://doi.org/10.1016/j.cmpb.2016.10.014

5. Fumagalli F., Silver A. E., Tan Q., Zaidi N., Ristagno G. (2018), Cardiac rhythm analysis during ongoing cardiopulmonary resuscitation using the Analysis During Compressions with Fast Reconfirmation technology, Heart Rhythm, 15 (2). P. 248-255. DOI: https://doi.org/10.1016/j.hrthm.2017.09.003

6. Napoli N. J., Demas M. W., Mendu S., Stephens C. L., Kennedy K. D, Harrivel A. R, Bailey R. E., Barnes L.E. (2018), Uncertainty in heart rate complexity metrics caused by R-peak perturbations, Computers in Biology and Medicine. 103. P. 198-207. DOI: https://doi.org/10.1016/j.compbiomed.2018.10.009

7. Napolitano A. (2016) Cyclostationarity: Limits and generalizations. Signal Processing. Vol. 120. March 2016. P. 323-347. DOI: https://doi.org/10.1016/j.sigpro.2015.09.013

8. Lepage R., Boucher J., Blan J. and Cornilly J., «ECG segmentation and p-wave feature extraction: application to patients prone to atrial fibrillation», IEEE EMBS 2001; 1:298-301.

9. Moody B. G. and Mark R. G., "A new method for detecting atrial fibrillation using R-R intervals", IEEE Computers in Cardiology 1983; 10:227-230.

10. Cerutti S., Mainardi L. T., Porta A. and Bianchi A. M., «Analysis of the Dynamics of RR Interval Series for the Detection of Atrial Fibrillation Episodes», IEEE Computers in Cardiology 1997; 24:77-80.

11. Tateno K. and Glass L., «A Method for Detection of Atrial Fibrillation Using RR intervals», IEEE Computers in Cardiology 2000; 27:391-394.

12. Karyotis V., Khouzani M. H. R. (2016) Malware Diffusion Models for Modern Complex Networks. Theory and Applications. USA. 2016. P. 324. ISBN 978-0-12-802714-1.

13. Sericola B. (2013) Markov Chains: Theory and Applications. London, July 2013. P. 416. ISBN: 978-1848-21493-4. DOI: https://doi.org/10.1002/9781118731543.ch1 
14. Shaffer F., Ginsberg J. P. (2017), An Overview of Heart Rate Variability Metrics and Norms, Frontiers in Public Health. Volume 5. Article 258. September 2017. P. 1-17. DOI: https://doi.org/10.3389/fpubh.2017.00258

15. Berkaya S. K., Uysal A. K., Gunal E. S, Ergin S., Gunal S., Gulmezoglu M. B. (2018), A survey on ECG analysis. Biomedical Signal Processing and Control, 43, 216-235. DOI: https://doi.org/10.1016/j.bspc.2018.03.003

16. Shen C., Yu Z., Liu Z. (2015), The use of statistics in heart rhythm research: a review, Heart Rhythm, 12 (6), 1376-1386. DOI: https://doi.org/10.1016/j.hrthm.2015.03.016

17. Peter Olofsson, Mikael Andersson. Probability, Statistics, and Stochastic Processes. John Wiley \& Sons, INC, 2012. USA. P. 553. DOI: https://doi.org/10.1002/9781118231296

18. Athanasios Christou Micheas. Theory of Stochastic Objects Probability, Stochastic Processes and Inference. Chapman and Hall/CRC. January 24. 2018. P. 408. ISBN: 9781466515215.

19. Hisashi Kobayashi, Brian L. Mark, William Turin. Probability, Random Processes, and Statistical Analysis. USA by Cambridge University Press, New York 2012. P. 812. Hardback 978-0-521-89544-6.

20. Oliver C. Ibe. Fundamentals of Applied Probability and Random Processes. 2nd Edition. Academic Press is an imprint of Elsevier. USA 2014. P. 431.

21. Scott Miller, Donald Childers Probability and Random Processes: With Applications to Signal Processing and Communications. 2nd Edition. Academic Press is an imprint of Elsevier. USA 2012. P.593. DOI: https://doi.org/10.1016/B978-0-12-386981-4.50011-4

22. Ben Salah R., Hadidi T. and Chabchoub S., «Intelligent diagnosis method of cardiovascular anomalies using medical signal processing,» 2015 World Congress on Information Technology and Computer Applications (WCITCA), Hammamet, 2015, P. 1-5. DOI: https://doi.org/10.1109/WCITCA.2015.7367032

23. Rahimpour M., Asl M. E. and Merati M. R., «ECG fiducial points extraction using QRS morphology and adaptive windowing for real-time ECG signal analysis,» $201624^{\text {th }}$ Iranian Conference on Electrical Engineering (ICEE). Shiraz. 2016. P. 1925-1930. DOI: https://doi.org/10.1109/IranianCEE.2016.7585836

24. Ciucurel C., Georgescu L., Iconaru E. I. (2018), ECG response to submaximal exercise from the perspective of Golden Ratio harmonic rhythm, Biomedical Signal Processing and Control, 40, 156-162. DOI: https://doi.org/10.1016/j.bspc.2017.09.018

25. Onyskiv P., Lupenko S., Lytvynenko I., Zozulia A. Mathematical modeling and processing of high resolution rhythmocardio signal based on a vector of stationary and stationary related random sequences. IDDM'2020: 3rd International Conference on Informatics \& Data-Driven Medicine, November 19-21, 2020, Växjö, Sweden. CEUR Workshop Proceedings, 2020, 2753, pp. 149-155. URL: http://ceurws.org/Vol-2753/short8.pdf.

26. Горкуненко А. Б., Лупенко С. А. Обгрунтування діагностичних і прогностичних ознак в інформаційних системах аналізу та прогнозування випадкових економічних процесів. Науковий вісник НЛТУ України: збірник науково-технічних праць. 2012. № 22.9. 347-352 c.

27. Lupenko S., Lytvynenko I., Stadnyk N. Method for reducing the computational complexity of processing discrete cyclic random processes in digital data analysis systems Scientific Journal of the Ternopil national technical university. 2020. Vol. 97. No. 1. P. 110-121. URL: https://doi.org/10.33108/visnyk_tntu. DOI: https://doi.org/10.33108/visnyk_tntu2020.01.110

28. Lupenko S., Lytvynenko I., Stadnyk N., Zozulia A. та інші Mathematical model of rhythmocardiosignal in vector view of stationary and stationary-related case sequences. Advanced Information Systems. National Technical University «Kharkiv Polytechnic Institute». 2020. Vol. 4. No. 2. P. $42-46$. DOI: https://doi.org/10.20998/2522-9052.2020.2.08

29. Hutsaylyuk V., Lytvynenko I., Maruschak P., Schnell, G. та iншi.A new method for modeling the cyclic structure of the surface microrelief of titanium alloy ti6al4v after processing with femtosecond pulses. Materials, 2020, 13(21), pp. 1-8, 4983. DOI: https://doi.org/10.3390/ma13214983

30. Marushak P. O., Lytvynenko I. O., Lupenko S. A., Popovych P. V. Modeling of the Ordered Surface Topography of Statically Deformed Aluminum Alloy. Materials Science. 2016. Vol. 52. No. 1. P. $113-122$. DOI: https://doi.org/10.1007/s11003-016-9933-1 


\title{
УДК 004.652
}

\section{КОНЦЕПЦІЯ ПОБУДОВИ, ВИМОГИ ТА УЗАГАЛЬНЕНІ АРХІТЕКТУРИ СКЛАДОВИХ ІНТЕГРОВАНОГО ОНТООРІЕНТОВАНОГО ІНФОРМАЦЙНОГО СЕРЕДОВИЩА МОДЕЛЮВАННЯ ТА ОПРАЦЮВАННЯ ЦИКЛІЧНИХ СИГНАЛІВ}

\section{Сергій Лупенко ${ }^{1}$; Ярослав Литвиненко ${ }^{1}$; Володимир Готович ${ }^{1}$; Андрій Зозуля²; Чізоба Ннамене ${ }^{1}$; Олександр Воляник²}

\author{
${ }^{1}$ Тернопільський національний технічний університет імені Івана Пулюя, \\ Тернопіль, Україна \\ ${ }^{2}$ Інститут телекомунікаиій і глобального інформаційного простору \\ Наџіональної академії наук Украӥни, Київ, Украӥна
}

Резюме. Обтрунтовано актуальність розроблення, а також формулювання загальних вимог та побудову узагальненої архітектури інтегрованого онтоорієнтованого інформаційного середовища моделювання й опраџювання цииклічних сигналів на базі теорії циклічних функціональних відношень. Це дозволило ефективно системно вирішити цілий спектр важливих методологічних, методичних та технологічних завдань у галузі моделювання та опрацювання цииклічних сигналів. Зокрема, суттєво спростило, інтенсифікувало (автоматизувало) та підвищило ступінь достовірності процедури розроблення математичного й програмного забезпечення інтелектуалізованих систем для потреб медииини, техніки та економіки. Сформульовано основні завдання розроблення та розроблено узагальнену архітектуру інтегрованого онтоорієнтованого інформаційного середовища моделювання й опрацювання ичиклічних сигналів. Сформульовано вимоги та розроблено узагальнені архітектури таких складових інтегрованого онтоорієнтованого інформаційного середовища моделювання та опрацюювання ичиклічних сигналів: інформаційної онтоорієнтованої довідкової системи в галузі моделювання та опрачювання циклічних сигналів; бази знань інтегрованого інформаційного середовища, ядром якої є онтологія предметної області «Моделювання та опрацювання ичиклічних сигналів у рамках теорії ичиклічних функиіональних відношень»; експертної онтоорієнтованої системи підтримки прийняття рімень у галузі моделювання ц̌ опращювання циклічних сигналів, інформаційної системи з онтоорієнтованою архітектурою для моделювання та опрацювання циклічних сигналів. 